\title{
THE LEIOGNATHIDAE (TELEOSTS): AN HYPOTHESIS RELATING THEIR MEAN DEPTH OCCURRENCE TO THE INTENSITY OF THEIR COUNTERSHADING BIOLUMINESCENCE
}

by

\author{
DANIEL PAULY ${ }^{1)}$
}

\begin{abstract}
All species belonging to the Family Leiognathidae (genera Leiognathus, Secutor \& Gazza) are bioluminescent. They emit during daytime a downward, diffuse light which tends to disrupt their silhouette, making them less discernible from beneath to potential predators. It is here assumed that the intensity of light emitted should correspond to the intensity of incident light at the depth at which each species generally occurs. Using published information on the relative intensity of emitted light in different species and quantitative data on the mean depth occurrence of the species, it is shown that there is a good correspondance in the ranking order of both light intensity and depth occurrence in five species (e.g. Secutor ruconius emits a strong light and occurs in shallow water; Leiognathus elongatus emits a weak light and occurs at greater depth). Species not fitting into this pattern (e.g. Leiognathus splendens emits a weak light but occurs in very shallow water) tend to occur in murky water, where less light is required for counterillumination.
\end{abstract}

\section{INTRODUCTION}

\section{Bioluminescence in fishes}

Light organ in fishes were first discovered by Cocco in 1838 in Mediterranean deep-water fishes (BERTIN 1958). In fact, most of the bioluminescent fishes recorded are from the meso/bathypelagial. In these zones bioluminescence may fulfill a variety of inter- and intraspecific functions, such as luring and illuminating prey, confusing potential predators, attracting sexual partners, other members of the same species or assisting in schooling (BERTIN 1958; BURKENROAD 1943; MCALLISTER 1967; MORIN et al 1975).

The light organs may be located on or in widely different parts of the body such as for example around the mouth, along the flanks, on the back, abdomen and protruding organs (for a review on the occurrence, position and possible function of bioluminescent organs in fishes see MCALLISTER 1967). Me ALLISTER (1967) pointed out that many luminescent fishes display ventral bioluminescence and stressed that "fishes possess photophores for a

1) Indonesia-German fisheries Development Project, P.O. Box 198 Semarang, Indonesia. 


\section{DANIEL PAULY}

number of reasons but they are placed ventrally because this results in reduced predations. This applies to bathypelagic fishes whose predominantly ventral light cannot be seen from predator species swimming above them as well as for close inshore species where the ventral position of the light organ may result, during day time in a "counter-" or "disruptive" illumination which may decrease predation from below.

Thus, the best explanation for the function of light emission in a great number of shallow water bioluminescent fishes appears to be that of counterillumination, an hypothesis first put forward by JERZMANSKA (1960, vide MCALLister 1967). MCAllister (1967), refering to this hypothesis, suggested that it may well apply to those acanthopterigian displaying internal light organs and transparent venter, SUCH as the Trachidae, or the Leiognathidae.

\section{Bioluminescence in Leiognathidae}

The Leiognathidae, consisting of the genera Leiognathus LACEPEDE 1805, Secutor GISTEL 1848 and Gazza RUPPEL 1835 are commenly known as slipmouths (official FAO — name), pony-fishes, silver-bellies, pouters, slimies, and are widely spread over the Indo-Pacific with about 30 species. Most of these have already been reported to be bioluminescent and bioluminescence is highly probable for the rest. The bioluminescence of these small fishes was first discovered by HARMS (1928) who described the light organ of Equula sp. (Leiognathus splendens according to AHRENS 1965). BLEgVAD (1944) erroneously attributed the light emission by Leiognathus sp. to the food consumed by these fishes which he believed to consist exclusively of luminescent plankton organisms. HANEDA (1940), working without knowledge of HARMS' publication, rediscovered leiognathid bioluminescence in Gazza minuta. Other papers on the structure of the light organs of Leiognathids followed (HANEDA 1950, AHRENS 1965, BASSOT 1966, HANEDA \& TSUji 1972). BoISVERT et. al (1967) and HASTINGS \& MitCHELL (1971) described extensively the symbiotic bacteria which cause the glandular light organ of the slipmouth to glow (Figure 1).

HASTINGS (1971) discussing the function of ventral luminescence in leiognathids refered to the countershading hypothesis, from which he derived a set of features required from light emitted by pony-fish, which should possibly:

- be emitted in a continuous glow.

- occur at day,

- be regulated as to always truly match the background. 


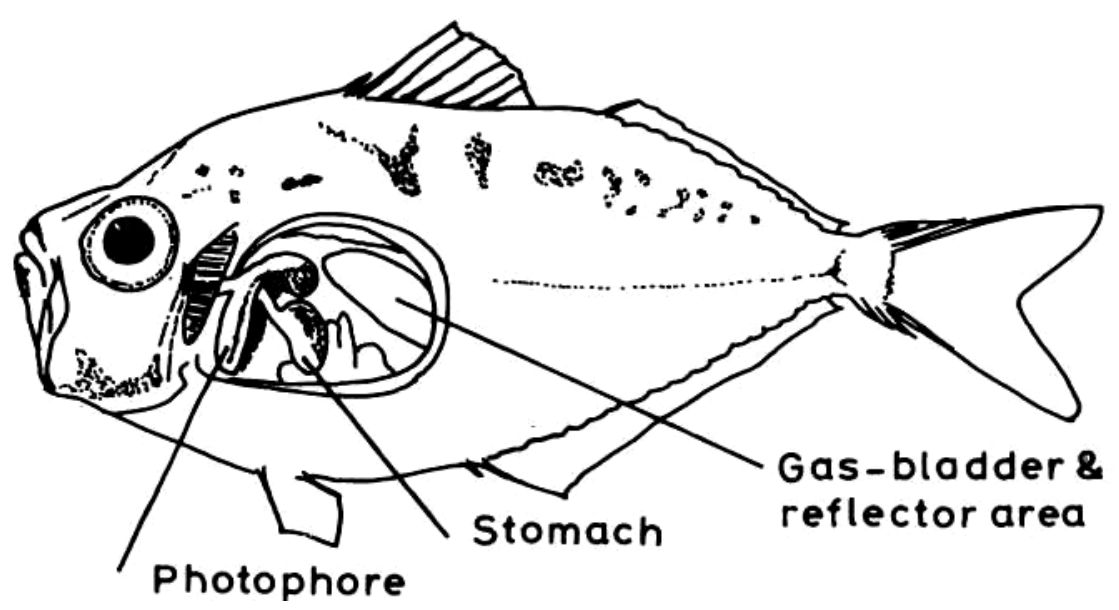

Figure 1. Light organs of Leiognathus hatai (redrawn after HANEDA \& TSUJI 1972).

Noting that the Leiognathids possess all these features, HASTINGS (1971) went on to mention some assumed drawbacks of the hypothesis:

- there is no data on the effect of incident irradiation on the

- intensity of bioluminescent emission.

- there is a general lack of ecological data on these fishes, and finally

- they are bottom dwellers, where the silhouette-concealing

- mechanism would seem to be of little value.

The latter point does not seem to be a serious drawback to the counterillumination hypothesis since the leiognathids, like most other reportedly bottom dwelling fishes generally swim several decimeters or even meters above the botom, thus exposing themselves to potential predators swimming beneath. The present work presents a preliminary attempt to verify the counter-illumination hypothesis on the basis of ecological data, namely the mean depth occurence and the habitat of seven species of leiognathid fishes.

The hypothesis

The counterillumination hypothesis implies that, in order to be effective, the light produced by the fish should match the intensity of incident light in water depth at which the fish generally occurs.

Basically, the hypothesis can be tested in two ways:

in an experiment, by recording the light emission of one or several individuals in relation to an incident light whose intensity can be varied experimentally, as proposed by HASTINGS (1971). 


\section{DANIEL PAULY}

with field data, and along evolutionary lines, by relating the light intensity of leiognathid species to their mean depth occurrence, over a series of species.

Thus, the first approach would consist of investigating the possibility to regulate an existing capability (light emission) in a given species, while the second approach would determine the existence of different inherent levels of capability in different species.

The second approach suggested itself to the author during the course of an exploratory bottom trawling survey in the Jawa and South China Seas, where the species composition of Leiognathidae was found to be different at different depths. In deep water the Secutor species, known to emit a strong light, and Leiognathus splendens and L. equulus were gradually replaced by $L$. bindus and L. elongatus, the latter of which is known to emit a feeble light only (HANEDA 1950).

\section{MATERIAL AND METHODS}

Mean depth occurrence of leiognathid species

As the number of trawl catches sorted to species level during the cruises mentioned above was too low, data are used here which were gathered by WEBER (pers. comm.) in a similar cruise in the waters off North Borneo in 1972, where 112 of the bottom trawl hauls made yielded leiognathids. The depth distribution of these positive hauls is shown in Table I. The trawl was an unmodified "Thailand-Trawl".

TABLE I. Depth distribution of hauls where leiognathids were caught (after WEBER, pers. comm.)

\begin{tabular}{|l|c|c|c|c|c|c|c|c|c|}
\hline depth in m & $<20 *$ & $20-24$ & $25-24$ & $30-34$ & $35-39$ & $40-44$ & $45-49$ & $50-54$ & $>55 *$ \\
\hline $\begin{array}{l}\text { number of } \\
\text { hauls }\end{array}$ & 4 & 13 & 24 & 19 & 15 & 16 & 10 & 7 & 4 \\
\hline
\end{tabular}

* Note: For averaging, $<20 \mathrm{~m}$ was uniformely considered to correspond to $15-19 \mathrm{~m}$ and $\geqslant 55 \mathrm{~m}$ to $55-59 \mathrm{~m}$. 
The occurrence of eight leiognathid species in the positive stations was recorded and expressed as percentage occurrence in the positive stations in each depth range. These percentage values were then averaged to obtain the weighted mean depth occurrence.

\section{Relative intensity of bioluminescence}

There are no quantitative data on the light emission of leiognathids which could be used to establish a ranked list of relative light intensity. Here, subjective accounts on the relative light intensity of the species investigated have been used.

From HANEDA (1940) the following information were extracted:

"The luminescence is more intensive in Gazza minuta than in $L$. equulus, but the latter is also lightning distinctly".

"The luminescence of Secutor insidator and S. ruconius is the strongest, while that of. . . L. splendens ... is mild".

From HANEDA (1950).

"Gazza minuta occurs in clear water in Palao at the depth about $30 \mathrm{~m}$, and $L$. equulus lives in turbid water in the vicinity of mangrove trees at the depth of $1 \quad 2 \mathrm{~m} "$.

"L. elongatus is an offshore species ... and ... possesses a very small luminous organ. In consequence, its luminousity is feeble". "Secutor insidiator and .V. ruconius are luminous leiognathids ... possessing relatively larger luminous organs than does G. minuta".

In addition, the present author considers that in $S$. ruconius the light and associated organs have evolved further than in S. insidiator.

\section{RESULTS}

The ranked list of species arranged according to the intensity of their bioluminescence is as follow:

$$
\text { L. splendens }
$$

A) S.ruconius $<$ S. insidiator $<$ G.minuta $<$ L.equulus $<$ L.elongatus

\section{L. bindus}

L. splendens and L. equulus $s_{l}$ however, should be considered differently as they are known to occur mainly in turbid inshore water (HANEDA 1940 and 1950; ChABANne \& Plante 1969; PAUly 1976 and see below) where the downwelling light intensity does not decrease with the same factor as in clear water. 


\section{DANIEL PAULY}

This leaves the following lists of species, whjch are attributed ordinal numbers:

B) S. ruconius (1), S. insidiator (2), G. minuta (3), L. bindus (4), L. elongatus (5).

Figure 2 shows the depth distribution and mean depth occurrence of eight species of leiognathids from which $L$. splendens, L. equulus, and L. leuciscus should be removed to allow for comparison. The ranked list is thus:

C) S. ruconius (1), G. minuta (3), S. insidiator (2), L. elongatus (5), L. bindus (4) (in list $\mathrm{C}$, the number in brackets are the ordinal numbers of list B).

Lists B and C (Table II) have a coefficient of rank correlation of 0.6 which is significant at the 5\% level (SOKAL \& ROHLF 1973).

TABLE II. Ranked order of relative light intensity against mean depth of occurrence

\begin{tabular}{ll|l|l|l|l|l|l} 
B $\quad$ relative light intensity & 1 & 2 & 3 & 4 & 5 & $\mathrm{r}=06$ \\
\hline C & mean depth occurrence & 1 & 3 & 2 & 5 & 4 &
\end{tabular}

\section{DISCUSSION}

The probable existence of an inverse relationship between the intensity of bioluminescence and the mean depth occurrence in some leiognathid species argues for the validity of HASTINGS' (1971) hypothesis that the light emitted by pony-fish has the effect of disrupting their silhouette, hence to reduce predation from below.

The elimination of $L$. splendens and L. equulus from list A seem to be justified by the fact that these two species do show a special adaptation to a life in turbid water, namely a profuse slime production (these two species are by far the "slimiest" of the seven species considered).

NIKOLSKI (1963) explains that such an intensive slime production is often found as an adaptation to a life in turbid water, the slime surrounding the fish causing the suspended matter to flocculate, thus enlarging the fish's field of vision. This effect, together with a diagrammatic representation of the main idea expressed in the present paper, is shown in Figure 3. 

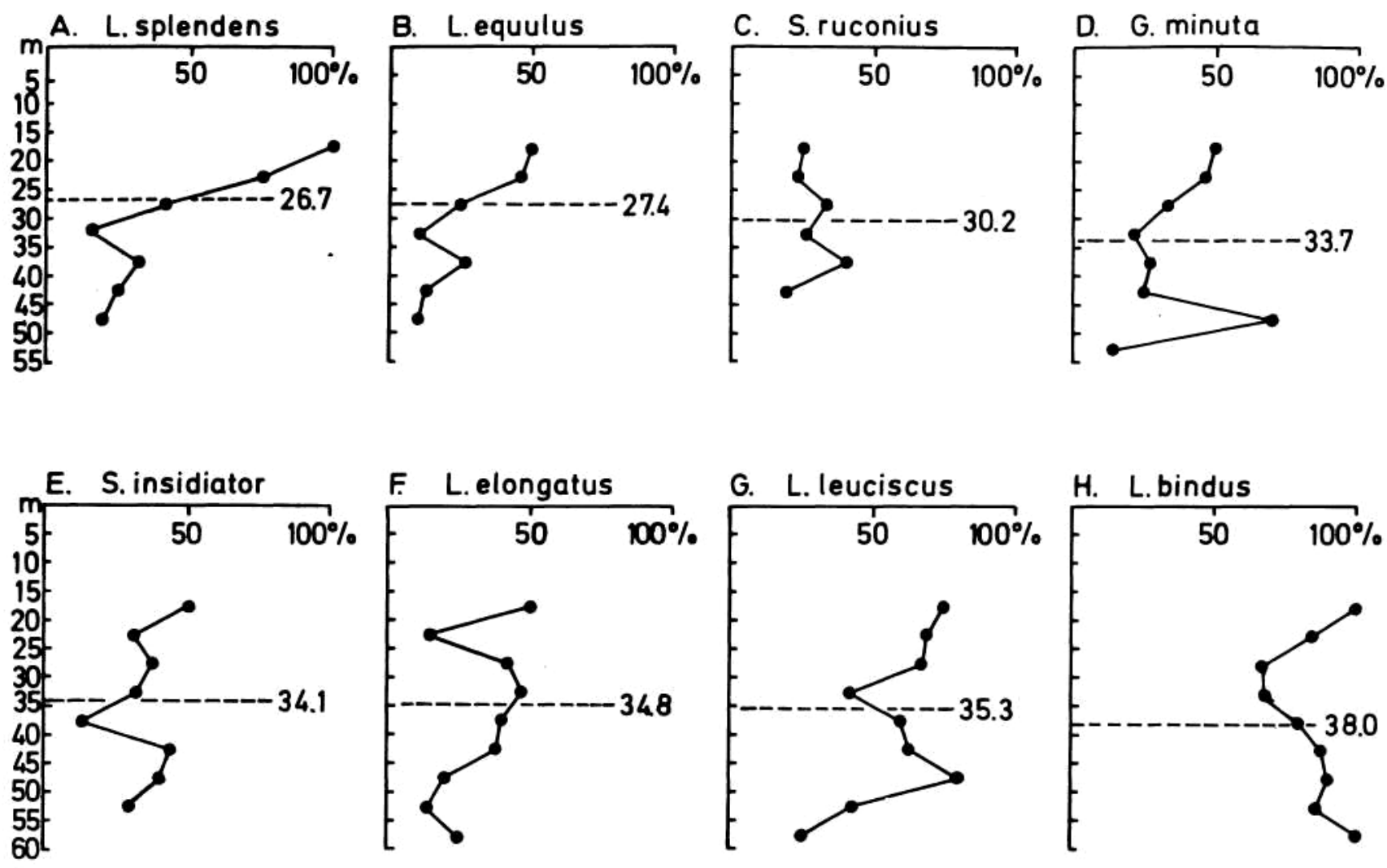

Figure 2. Depth distribution and mean depth occurrence of eight leiognathid species (after data from WEBER, personal communication). 


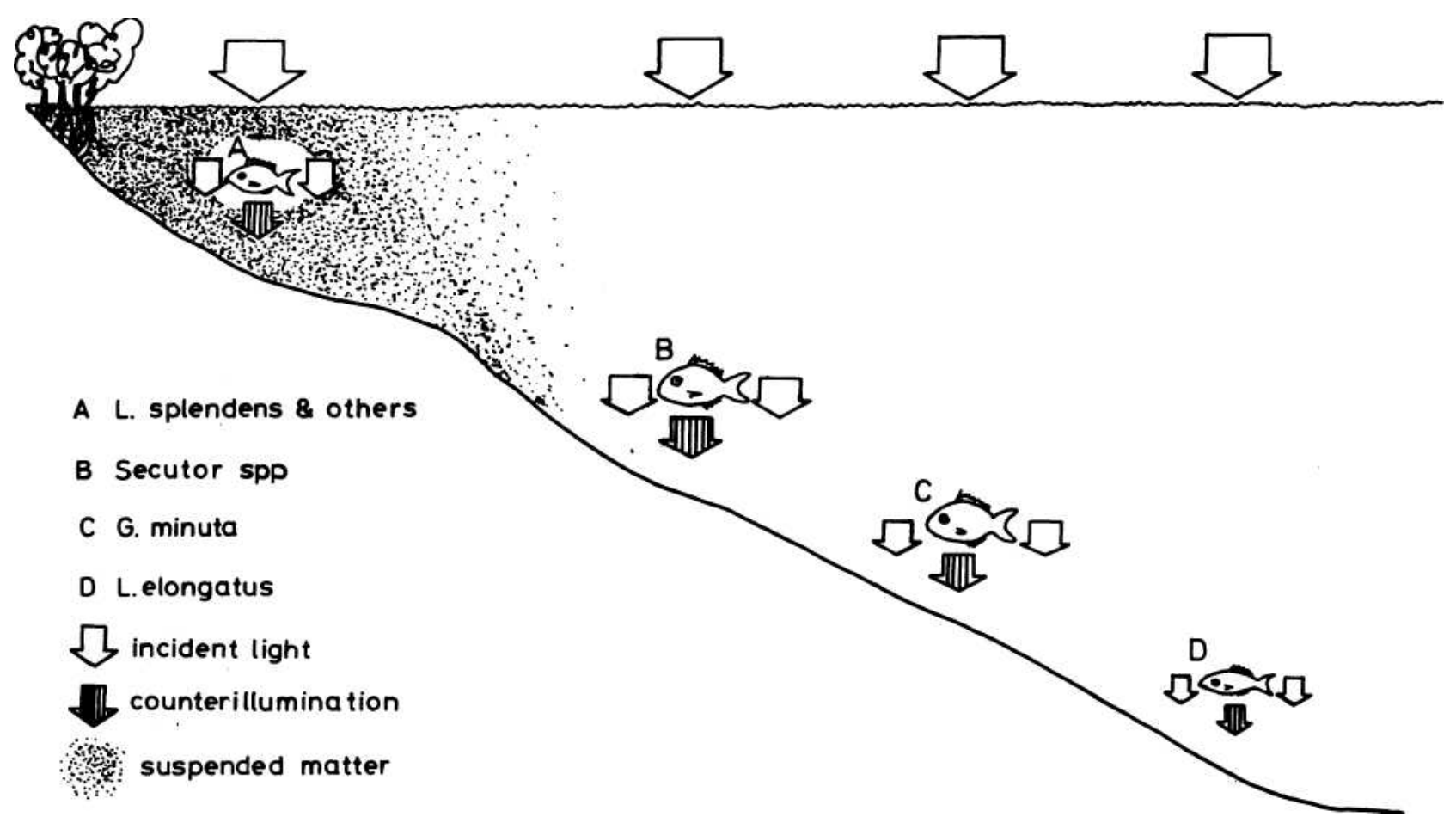

Figure 3. Diagrammatic representation of the depth distribution of leiognathid species and its relationship to incident light and counterillumination. 
The counterillumination hypothesis takes into account the remark by BERTIN (1958) that the position of the light organ and the shape of the reflector suggest the ambient medium is actually illuminated by the pony-fish.

It does not explain, however, why flashes of light are emitted both at night and by day (BALAN 1967; LOSSE pers. comm.), which seem to be produced when the fishes are excited. BASSOT (1966) even suspects that only the light produced after a strong excitation (e.g. by Adrenalin) can be seen through the body wall, but this statement does not hold in the face of the many reports of a continous emission of glowing light (HARMS 1928; HANEDA 1940, 1950; HASTINGS 1971).

Possibly the leiognathids developed a secondary function for their ability to luminesce which would explain the relationship between excitation and flashing light. An explanation may be the "burglar-alarm effect" (BURKENROAD 1943) where an organism - here a fish - attacked or threatened by predators reveals the presence of the latters to second order predators.

The present work is of a very preliminary nature, and the "counterillumination hypothesis" still needs confirmation in a series of experiments. In vitro or better in vivo photometric measurements of the intensity of light emission and their possible regulation in different species would be most adequate, and these measurements should be related to the mean downwelling light intensity in the various leiognathid habitats.

\section{ACKNOWLEDGEMENTS}

The author is indepted to DR. W. WEBER German Federal Board of Fisheries, who contributed his data on depth occurrence of leiognathid species, and to DR. Y. HANEDA for sending copies of even his oldest papers as well as comments on the manuscript. MR. G.F. LOSSE critically read the first draft of this paper and PROF. J.W. HASTINGS kindly helped revising the manuscript and formulating some of the ideas expressed here.

\section{REFERENCES}

AHRENS, G. 1965. Untcrsuchungen am Leuchtorgan von Leiognathns klunzingeri (Steindachner) Z. Wiss Zool. 173 : 90 - 113.

BALAN, V. 1967. Hiology of the silver-belly, Leiognathus bindus (Val.) of the Calicut Coast. Indian J. Fish. 10 A ( l ) : $118-134$. 


\section{DANIEL PAULY}

BASSO I, J.M. 1966. On the comparative morphology of some luminous organs. In: Bioluminescence in Progress (Johnson \& Haneda eds.). The Colonial Press Inc. U.S.A. 557610.

BERTIN, 1958. Organes lumineux. In: Grasse, Traite de Zoologie vol 73 (Teleostei). Massons et Cie. Paris.

BLECVAI), H. 1944. Fishes of the Iranian Gulf. Danish Scientific Investigation in Iran, 3 :247 pp. Copenhagen.

BOISVERT, H.; K. CHATELAIN and J.M. BASSOT 1967. Etude d'un photobacterium isole de l'organe lumineux de poissons Leiognathidae. Ann. Inst. Pasteur. 112 (4) : 520524.

BUKKENROAD, M.I). 1943. A possible function of bioluminescence. ./. Marine Res. 5 : 161 - 164.

CHABANNE, J. and R. PL ANTE 1969. Les populations benthique (endofaune, crevettes penaeides, poissons) d'une baie de la cote nord ouest de Madagascar: ecologie, biologic et peche. Cahier ORSTOM Ser. Ocean. 7 (1): $41-71$.

HANEDA, Y. 1940. On the luminescence of the fishes belonging to the family Leiognathidae of the Tropical Pacific. Palao Trop. Biol. Station Studies 2(1):29- 39.

HANEDA, Y. 1950. Luminous organ offish which emits light indirectly. Pacific Science 4 (3) : 214 227.

HANEDA, Y. and F.J. TSUJI 1972. The luminous organs of two species of leiognathid fishes recently found in Ambon, Indonesia. Sci. Rep. Yokosuka City Mus. 19 : 7 - 11.

HARMS, J.W. 1928. Bau und Entwicklung cines eigenartigen Leuchtorgans bei Equula spec. (Teleost). Z. Wiss. Zool. 131 (1) : 157 - 179.

HASTINGS, J.W. 1971. Light to hide by: ventral luminescence to camouflage the silhouette. Science 173: 10161017.

HASTINGS, J.W. and G. MITCHELL 1971. Lndosymbiotic bioluminescent bacteria from the light organ of pony-fish. Biol. Bull. Mar. Lab. Woods Hole 141 (2) : 261 - 168.

JERZMANSKA, A. 1960. The structure and biological significance of light organs in the Teleostei. Przeglad Zoologically 4 : 12 - 118 (In Polish).

Me ALLiSTER, D.E. 1966. The significance of ventral bioluminescence in fishes. J. Fish. Res. Bd. Canada 24 (3) ; 537 - 554.

MORIN, J.Q., A. HARRINGTON; K. NEALSON; N. KRIEGER; I.O. BALDWIN and J.W.

HASTINGS, 1975. Light for All Reasons: Versatility in the Behavioral Repertoire of the Flashlight Fish. Science 190: 74 - 76.

NIKOLSKY, G.V. 1973. The ecology of fishes. Academic Press. London - New-York, 532 pp. 